\title{
BALEE INONG DAN PENGENDALIAN MASALAH-MASALAH SOSIAL REMAJA (STUDI KASUS DI KECAMATAN ULEE KARENG KOTA BANDA ACEH)
}

\author{
Akmal Saputra \\ Dosen Tetap Prodi Sosiologi FISIP-Universitas Teuku Umar \\ email: akmalsaputra@utu.ac.id
}

\begin{abstract}
Banda Aceh has uttered a local institution which was named Balee Inong that was managed by Gampong society (village) especially for woman. Balee Inong has to realize the role of civil society; including tackling the issue of juvenile delinquency, but not specifically institution for handles the issue of juvenile delinquency. One of the problems of juvenile delinquency preventive efforts can be done through education. Based on background of study above, this paper attempts to reveal how is Balee Inong's effort in instilling the values of education for adolescents who have problems of juvenile delinquency in the district of Ulee Kareng-Banda Aceh? How is Balee Inong's role in instilling the value of education to mothers in order to fortify and overcome the impact of deviant behavior as well as to educate their children? The theory used in this paper is the Local Institutions by Esman and Uphoff and Social Control Theory. The results showed that the role of women's centers Ceurih to make efforts to handle the problems of juvenile delinquency, carried out through educational patterns or increased capacity and using two methods, the first: through a direct approach, namely the efforts leading to the problems and issues being faced by adolescents; second: through the indirect approach, which attempts to do leads to a skill or capacity-building approach adolescence. Efforts and the roles are not limited to teenagers, but also performed on their mother, in order to fortify and overcome the impact of deviant behavior. Efforts and roles performed are: first, the increase in capacity can be made directly associated with social issues that are occurring with women's expectations of Balee Inong Ceurih can address the problem of juvenile delinquency; second, the majority of programs other capacity building undertaken by Balee Inong Ceurih, actually indirectly also directs women can fortify and tackling deviant behavior. Then, the control of social issues that was conducted by Balee Inong is preventative.
\end{abstract}

Keywords: Balee Inong, social control, juvenile delinquency. 


\section{PENDAHULUAN}

Pendidikan merupakan suatu kewajiban bagi setiap masyarakat baik yang muda maupun yang tua, tujuannya adalah untuk mencapai masyarakat yang madani, yaitu madani secara spritual, ekonomi, sosial, politik dan budaya. Islam selalu mengajarkan umatnya untuk terus belajar, ayat Al-Qur'an pertama sekali turun melalui malaikat Jibril untuk disampaikan kepada Rasululullah SAW adalah Iqra' artinya bacalah. Maka dapat diambil sebuah kesimpulan bahwa kita sebagai umat selalu diperintahkan belajar dan terus belajar, mulai dari ayunan hingga liang lahat.

Ketika menyinggung tentang pendidikan sebenarnya tidak hanya mengarah pada pendidikan formal saja namun juga pendidikan informal maupun non formal, pendidikan bisa saja didapatkan dimana saja dan kapan saja, tidak ada batas waktu untuk belajar, selama masih nyawa dikandung badan umat Islam harus selalu dan terus belajar. Menyinggung tentang pendidikan, pada dasarnya tidak ada pemisahan antara pendidikan umum dan pendidikan agama, hanya saja ada yang diutamakan terlebih dahulu, misalnya umat Islam diwajibkan untuk belajar Tauhid, Fiqh dan Tasawuf kemudian baru dilanjutkan dengan ilmu-ilmu lainnya.

Ilmu umum dan ilmu agama merupakan sebuah ilmu dan dituntut untuk terus kita pelajari agar menjadi dan mencapai masyarakat yang madani, misalnya umat Islam dituntut untuk dapat mengakses teknologi informasi, yang tujuannya adalah umat Islam bisa berdakwah dengan memanfaatkan teknologi dan informasi.

Era saat ini sudah masuk pada era globalisasi yang ditandai dengan perdagangan bebas, batas-batas administratif sebuah negara menjadi tidak tampak lagi, perkembangan teknologi dan informasi semakin cepat atau zaman sudah masuk pada zaman modern dan bahkan ada yang mengatakan sudah pada postmodern, banyak persoalan yang muncul kemudian, yang merupakan implikasi dari era globalisasi, baik dampak positif maupun negatif.

Dampak positif, teknologi dan informasi di era globalisasi akan menunjang aspek pendidikan akan semakin baik, misalnya pemanfaatan komputer, handphone dan internet. Namun, di sisi lain pemanfaatan teknologi dan informasi yang tidak pada tempatnya akan justru membuat masyarakat masuk ke dalam jurang keterpurukan. Hal ini bisa kita lihat bagaimana hari ini remaja dan masyarakat secara umum bisa mengakses situs-situs porno, melakukan seks bebas/pergaulan bebas, menjadi pemakai dan pengedar narkoba, pencurian, penipuan dan pembunuhan dengan memanfaatkan media teknologi dan informasi sebagai alatnya. Implikasinya akan berdampak pada kehidupan masyarakat di masa yang akan datang.

Dampak-dampak yang lain bisa kita lihat bagaimana kesemrautan kehidupan masyarakat, karena masyarakat harus terus bersaing di era globalisasi, ketika persaingan itu terjadi justru ketimpangan dan kesenjangan tidak dapat kita hindari, yang kaya akan semakin kaya dan yang miskin akan semakin miskin, kriminalitas juga akan semakin meningkat.

Di era yang yang seperti ini justru yang paling rentan terkena dampak adalah remaja, karena remaja dianggap masih berada pada posisi yang belum kuat secara prinsip dan kemudian masih mudah untuk diombang-ambing oleh 
perkembangan zaman. Melihat fenomena ini, maka reaktualisasi nilai-nilai Islam bagi masyarakat dan remaja perlu dilakukan untuk mengharmoniskan kembali masyarakat Indonesia khususnya masyarakat dan remaja kota Banda Aceh.

Banda Aceh adalah ibu kota provinsi Aceh, yang berlaku syariat Islam. Adapun misi dan visi kota Banda Aceh adalah mewujudkan kota yang madani, madani dari segala aspek: agama, pendidikan, sosial, ekonomi, budaya dan sebagainya. Kehidupan masyarakat di Banda Aceh sangat heterogen, banyak pendatang di kota Banda Aceh yang berlatar belakang berbeda. Sehingga banyak persoalan yang terjadi hari ini di kota Banda Aceh sekaligus Aceh secara umum. Sadar atau tidak generasi Aceh hari ini sedang dibutakan oleh kenikmatan sesaat dan kesengsaraan selamanya, mereka disuguhkan dengan berbagai kenikmatan seperti Narkoba dan seks bebas (Hasil survey Dinas Kesehatan Aceh. 70 Persen Pelajar Lakukan Seks Bebas. Tanggal 17 February 2013 dalam m.jpnn.com, diakses pada tanggal 29 September 2016). Masalah-masalah sosial lainnya yang muncul seperti pembunuhan, pemerkosaan, pelecehan seksual, pencurian, perampokan, penipuan dan sebagainya.

Hasil wawancara dengan masyarakat di kecamatan Ulee Kareng yang merupakan bagian dari wilayah Kota Banda Aceh adalah remaja hari ini mulai dipengaruhi oleh tindakan-tindakan yang menyimpang, seperti: menjadi pengguna narkoba, pengedar narkoba, pencurian, bolos sekolah dan sebagainya. Alasan inilah yang menjadi pertimbangan peneliti mengapa memilih lokasi penelitian di Kecamatan Ulee Kareng. Alasan lainnya adalah di kecamatan Ulee Kareng telah ada institusi lokal yaitu Balee Inong yang punya peran penting untuk membentengi pengaruh perilaku menyimpang dan mewujudkan masyarakat yang madani. (Wawancara awal dengan anggota Balee Inong Ceurih Ulee Kareng, tanggal 10 Maret 2015).

Reaktualisasi nilai-nilai Islam bagi masyarakat dan remaja telah dilakukan oleh berbagai kalangan di Kecamatan Ulee Kareng, termasuk institusi lokal yaitu Balee Inong, mereka sudah melakukan upaya-upaya penyelesaian masalah, misalnya melakukan penelitian sederhana untuk mengetahui masalah yang terjadi dan melakukan musyawarah dengan perangkat gampong untuk menyelesaikan masalah di kecamatan Ulee Kareng.

Balee Inong yang merupakan sebuah wadah dan tempat perempuan untuk meningkatkan kapasitas perempuan dan menyelesaikan masalah-masalah sosial, ekonomi, politik, budaya dan pendidikan yang ada di gampong dan kecamatan. Balee Inong hanya ada di Kota Banda Aceh saja, tidak ada di daerah yang lain di Indonesia. Pemberdayaan institusi lokal menjadi sangat penting dalam hal menyelesaikan masalah-masalah yang ada di lingkungan masyarakat. Institusi lokal merupakan sebuah institusi yang ada di masyarakat, artinya bahwa institusi lokal ini akan lebih dan sangat paham dengan kondisi masyarakat sendiri, Institusi lokal menjadi jembatan untuk menyelesaikan masalah-masalah sosial yang ada dimasyarakat.

Berdasarkan permasalahan di atas, peneliti ingin mengetahui; pertama, bagaimanakah upaya institusi lokal khususnya Balee Inong dalam menerapkan nilainilai pendidikan bagi remaja yang mengalami masalah-masalah sosial, misalnya terlibat menjadi pengguna narkoba, pengedar narkoba, pencurian, bolos sekolah dan sebagainya; kedua, bagaimanakah peran Balee Inong dalam meningkatkan 
kapasitas perempuan, khususnya orang tua perempuan (ibu-ibu) agar dapat membentengi diri dan menanggulangi pengaruh perilaku menyimpang, sekaligus dapat mendidik anak-anaknya karena ibu-ibu yang akan banyak bersosialisasi dan mendidik anak-anaknya di rumah.

Adapun yang menjadikan penelitian ini menarik untuk diteliti adalah, pertama, belum pernah ada yang meneliti tentang Balee Inong dan Pengendalian Masalah-Masalah Sosial Remaja di Kecamatan Ulee Kareng Kota Banda Aceh; kedua, Balee Inong hanya ada di Kota banda Aceh, tidak ada Balee Inong di daerah lain di seluruh Indonesia; ketiga, penelitian ini sangat penting agar menjadi acuan bagi pemerintah, perguruan tinggi, LSM dan mengambil kebijakan di kemudian hari; keempat, remaja adalah generasi penerus bangsa ini, oleh karena remaja perlu diselamatkan dari lembah kehancuran.

\section{LANDASAN TEORI}

\section{Institusi Lokal}

Esman dan Uphoff dikutip oleh Soetomo, institusi pada tingkat lokal merupakan saluran penghubung antara sektor privat dan sektor publik, dapat diklasifikasikan enam macam, yaitu: (Soetomo, 2008 : 456-457).

1. Administrasi lokal merupakan perwakilan departemen pemerintah pusat pada tingkat lokal

2. Pemerintahan lokal mempunyai otoritas untuk menyelenggarakan pembangunan dan membuat regulasi yang dipertanggungjawabkan kepada warga masyarakat

3. Asosiasi lokal yang keanggotaannya bersifat sukarela, yang dikembangkan untuk berbagai tujuan

4. Koperasi yang merupakan alat kerjasama anggota untuk memperoleh keuntungan ekonomis

5. Organisasi pelayanan lokal yang mewadahi warganya dalam saling membantu secara timbal balik

6. Usaha ekonomi perorangan dibidang manufaktur, perdagangan atau jasa

Asosiasi lokal atau yang kemudian disebut dengan Institusi lokal merupakan institusi yang hidup dan tumbuh di dalam kehidupan masyarakat dengan keanggotaan yang bersifat sukarela. Institusi lokal ini dapat melakukan berbagai tindakan bersama yang diputuskan secara bersama dan tanggung jawab bersama, institusi lokal tidak dikendalikan dan tergantung dari program-program pemerintah. (Soetomo, $2008: 457$ ).

Institusi lokal merupakan sarana pemberdayaan masyarakat yang dinilai dapat menfasilitasi berbagai tindakan bersama, namun tentu saja belum efisien, oleh sebab itu dalam hal tertentu perlu dilakukan perubahan-perubahan sesuai dengan tuntutan perkembangan zaman. Untuk melakukan berbagai perubahanperubahan dapat dilakukan melalui proses belajar sosial. Menurut Soetomo, proses belajar sosial tersebut menggambarkan kemampuan manusia dan kelompok manusia sebagai makhluk belajar yang berperilaku demi mengubah dan merencanakan kembali perilaku tersebut. Proses belajar sosial ini berlangsung 
secara terus menerus yang didapat dari pengalaman bersama, bukan melalui pendidikan yang formal. (Soetomo, $2008: 456-457$ ).

\section{Pengendalian Sosial}

Joseph S. Roucek melihat pengendalian sosial dari aspek pendidikan, menurutnya pengendalian sosial adalah segala proses baik direncanakan maupun tidak yang bersifat mendidik, mengajak bahkan memaksa untuk mematuhi kaidahkaidah dan nilai-nilai sosial yang berlaku. (Elly M. Setiadi dan Usman Kolip, 2011: 252). 252).

Sifat-sifat Pengendalian Sosial: (Elly M. Setiadi dan Usman Kolip, 2011:

a. Pengendalian Sosial Preventif, yaitu segala bentuk pengendalian sosial berupa pencegahan terhadap perilaku menyimpang agar kehidupan sosial berada pada kondisi kondusif.

b. Pengendalian Sosial Represif, yaitu pengendalian sosial yang bertujuan mengembalikan kondisi deviasi menjadi kondisi yang kondusif.

\section{Kenakalan Remaja}

Kenakalan remaja diterjemahkan dari Juvenile Delinquency. Juvenile Delinquency berasal dari kata Juvenile yang berarti anak, dan Delinquency yang berarti kejahatan. Juvenile Delinquency secara etimologis berarti kejahatan anak. Juvenile Delinquency memiliki arti kejahatan yang dilakukan oleh anak remaja. Pada masa remaja dikenal dengan masa Strom dan Stres yaitu terjadi pergolakan emosi yang diiringi dengan pertumbuhan fisik dan pertumbuhan psikis yang bervariasi. lingkungan sosial tempat berinteraksi, membuat remaja dituntut untuk dapat menyesuaikan diri secara efektif. (http://hukum.unmuhjember.ac.id, diakses tanggal 18 April 2015).

Bentuk kenakalan remaja meliputi: (http://hukum.unmuhjember.ac.id, diakses tanggal 18 April 2015).

1. Kenakalan yang menimbulkan korban fisik pada orang lain: perkelahian, perkosaan, perampokan, pembunuhan, dan lain-lain.

2. Kenakalan yang menimbulkan korban materi: perusakan, pencurian, pencopetan, pemerasan, dan lain-lain.

3. Kenakalan sosial yang tidak menimbulkan korban di pihak orang lain: pelacuran, penyalahgunaan obat.

4. Kenakalan yang melawan status, misalnya mengingkari status anak sebagai pelajar dengan cara membolos, mengingkari status orang tua dengan cara minggat dari rumah atau membantah perintah mereka

5. Kenakalan Remaja Non Kriminal yang mengalami masalah jenis ini cenderung tertarik pada kesenangan-kesenangan yang sifatnya menyendiri, apatis terhadap kegiatan masyarakat atau sekolah. Remaja ini suka mengasingkan diri, menghindarkan diri dari kegiatan yang menumbuhkan kontak dengan orang lain. Perasaannya sangat peka dan 
mudah terluka, cepat tersinggung dan membesar-besarkan kekurangannya sendiri, dengan gejala umum sering menyendiri, melamun, apatis tidak bergairah, sangat mudah tersinggung, sangat mudah panik, sangat mudah bingung sehingga cenderung menjadi peminum, pemabuk, penghisap candu, narkotika, menjadi morfinis dan sebagainya, bahkan tega untuk bunuh diri.

\section{HASIL PENELITIAN DAN PEMBAHASAN}

\section{Sekilas Tentang Balee Inong di Kota Banda Aceh}

Balee Inong merupakan sebuah institusi lokal beranggotakan perempuan. Institusi lokal ini hanya ada di Kota Banda Aceh. Balee Inong dibentuk oleh pemerintah kota dalam rangka untuk mendukung percepatan pembangunan masyarakat dan menangani masalah-masalah sosial termasuk masalah kenakalan remaja, kekerasan dalam rumah tangga, masalah kemiskinan dan upaya-upaya untuk memberdayakan perempuan. Pemerintah kota Banda Aceh memahami bahwa pembangunan tidak hanya sebatas pembangunan infrastruktur dan ekonomi semata, namun lebih dari itu, termasuk pembangunan sosial, budaya, kesehatan, pendidikan dan Agama.

Untuk mempercepat proses pembangunan, walikota Banda Aceh juga telah menciptakan gagasan baru yaitu dengan melahirkan konsep musrena. Musrena sendiri hanya ada di Kota Banda Aceh, konsep musrena juga sama dengan konsep musrenbang (musyawarah perencanaan pembangunan) yang sering dilakukan di beberapa kabupaten dan kota lainnya. Namun, musrena lebih fokus pada perencanaan-perencanaan yang dilakukan oleh perempuan. Pada saat pelaksanaan musrena perempuan memiliki kesempatan yang penuh untuk dapat memberikan berbagai masukan-masukan atau pendapat untuk menyukseskan pembangunan.

Jika kita melihat pelaksanaan musrenbang, perempuan sedikit sekali mendapatkan peluang untuk dapat memberikan pendapatnya. Hal ini dikarenakan perempuan belum memiliki rasa percaya diri untuk memberikan berbagai pendapatnya, sehingga ide-ide atau gagasannya dan kebutuhan perempuan menjadi tidak tertampung. Berdasarkan fenomena ini kemudian lahirlah konsep musrena di Kota Banda Aceh.

Musrena yang dilaksanakan di Kota Banda Aceh yang merupakan gagasan Walikota bukanlah tandingan dari musrenbang, justru gagasan ini lahir untuk mensinergikan pembangunan, agar kebutuhan dan aspirasi perempuan dapat tertampung dalam perencanaan pembangunan. Kaitannya dengan Balee Inong Ceurih yang kemudian diberi nama Bungong Keumang, bahwa Balee Inong ini juga telah mampu memberikan masukan dan usulan untuk pembangunan pada saat dilaksanakan musrena. Masukan dan usulan yang diberikan oleh perempuan di Balee Inong ini dan Balee Inong lainnya tidak hanya terbatas pada program-program pemberdayaan ekonomi perempuan saja, namun juga program-program sosial lainnya termasuk kepedulian terhadap remaja. Keterlibatan perempuan dalam perencanaan pembangunan adalah salah satu upaya untuk menyukses pembangunan. 
Untuk menjawab masalah-masalah sosial dan upaya-upaya pembangunan masyarakat, pemerintah Kota Banda Aceh telah membentuk 18 (delapan belas) Balee Inong yang beranggotakan 90 (sembilan puluh) gampong yang tergabung dalam 18 (delapan belas) Balee Inong tersebut. 18 (Delapan Belas) Balee Inong ini dibina oleh pemerintah kota melalui WDC (Women Development Centre) dan PP\&KB (Pemberdayaan Perempuan dan Keluarga Berencana) Kota Banda Aceh. Adapun nama-nama Balee Inong adalah sebagai berikut:

1. Balee Inong Annisa' yang terletak di gampong Rukoh Kecamatan Syiah Kuala.

2. Balee Inong Kartini yang terletak di gampong Tibang Kecamatan Syiah Kuala.

3. Balee Inong Bitai yang terletak di gampong Bitai Kecamatan Jaya Baru.

4. Balee Inong Kuta Raja yang terletak di gampong Merduati Kecamatan Kuta Raja.

5. Balee Inong Geuceu Meunara yang terletak di gampong Geuceu Meunara Kecamatan Jaya Baru.

6. Balee Inong Lamjamee yang terletak di gampong Lamjamee kecamatan Jaya Baru.

7. Balee Inong Bungong Keumang Ceurih di gampong Ceurih di Kecamatan Ulee Kareng.

8. Balee Inong Mufakat di Gampong Lampulo

9. Balee Inong Raudhatunnisa' di Gampong Lhong Cut

10.Balee Inong Malahayati di Gampong Beurawe, Kecamatan Kuta Alam

11.Balee Inong Sejahtera di Gampong Ie Masen Ulee Kareng

12.Balee Inong Tgk Chiek Lamjabat di Kecamatan Meuraksa

13.Balee Inong Punge Jurong di Kecamatan Meuraksa

14.Balee Inong Cut Nyak Dasah Lampaseh di Kecamatan Meuraksa

15.Balee Inong Ilie di Kecamatan Ulee Kareng

16.Balee Inong Pante Rhiek di Kecamatan Lueng Bata

17.Balee Inong Ateuk Munjeng di Kecamatan Baiturrahman

18. Balee Inong Neusu Aceh di Kecamatan Baiturrahman.

Usulan-usulan yang telah dihasilkan pada saat musrena kemudian diserahkan kepada Keuchik (kepala desa), untuk disahkan dan kemudian dibahas pada musrenbang di tingkat Kecamatan masing-masing. Kegiatan musrena ini di fasilitasi oleh WDC yang merupakan perpanjangan tangan dari Pemerintah Kota Banda Aceh yang didukung oleh Ford Foundation.

Ada hal yang menarik dari Balee Inong Ceurih dan Balee Inong pada umumnya, untuk pelaksanaan kegiatan institusi sosial ini tidak selamanya menunggu pembiayaan dari pemerintah dan WDC, sekalipun mereka telah merancang program dan usulan saat pelaksanaan musrena, justru mereka mampu melaksanakan kegiatan-kegiatan secara mandiri dan swadaya anggota dan masyarakatnya.

\section{Upaya Balee Inong dalam Menanamkan Nilai-nilai Pendidikan Bagi Remaja yang Mengalami Masalah Kenakalan Remaja}

Apa yang peneliti uraikan di atas adalah sekilas informasi tentang Balee Inong yang ada di kota Banda Aceh. Mengamati beberapa program kerja yang telah dijalankan oleh Balee Inong Ceurih, baik di bidang sosial, pendidikan, keagamaan, 
budaya, ekonomi, kesehatan menunjukkan bahwa Balee Inong Ceurih telah melaksanakan upaya-upaya yang penting dalam menanamkan nilai-nilai pendidikan bagi remaja yang mengalami masalah kenakalan remaja, upaya yang dilakukan dapat terlihat secara langsung maupun tidak langsung. Langsung yang dimaksudkan adalah program yang dirancang mengarah pada permasalahan yang dihadapi oleh remaja, sedangkan tidak langsung mengarah pada kegiatan peningkatan kapasitas atau skill dengan tujuan agar remaja dapat melakukan halhal yang positif sehingga remaja tidak terlibat pada kegiatan-kegiatan yang menyimpang.

Program sosialisasi bahaya narkoba dan sosialisasi bahaya LGBT (Lesbian, Gay, Biseksual, Transgender) merupakan bagian dari program kerja Balee Inong Ceurih di bidang pendidikan. Program tersebut dapat terlihat langsung diarahkan kepada remaja, sebagai salah bentuk upaya preventif yang dilakukan oleh Balee Inong Ceurih dengan tujuan agar remaja tidak terjerumus pada perilaku yang menyimpang. Balee Inong Ceurih telah melakukan upaya-upaya penanaman nilainilai pendidikan melalui kegiatan tersebut. Kedua program kerja di atas yang dijalankan oleh Balee Inong Ceurih merupakan salah satu peran institusi lokal tersebut dalam menanamkan nilai-nilai pendidikan kepada remaja. Nilai-nilai pendidikan yang ditransfer kepada remaja selama ini tidak terlepas dari nilai-nilai Islam.

Pelatihan komputer, pelatihan public speaking, pelaksanaan berbagai kegiatan sosial dan keagamaan merupakan contoh upaya-upaya preventif yang dilakukan oleh Balee Inong Ceurih dalam menangani masalah kenakalan remaja secara tidak langsung. Kegiatan ini dilakukan untuk meningkatkan kapasitas perempuan, melatih dan meningkatkan skill perempuan, dan juga proses transfer ilmu untuk meningkatkan akhlak yang mulia bagi perempuan. Perempuan yang dimaksudkan disini tidak hanya perempuan yang dikategorikan dewasa, namun juga perempuan remaja. Pada proses berikutnya mereka secara tidak langsung akan mentransfer ilmu dan pengetahuannya kepada masyarakat umum, artinya pendidikan ini tidak hanya dirasakan oleh perempuan di Balee Inong saja, karena pada dasarnya Balee Inong adalah milik masyarakat.

Berdasarkan temuan dan analisis di atas, peran Balee Inong Ceurih dalam melakukan upaya-upaya menangani masalah-masalah kenakalan remaja, dilakukan dengan dua metode; pertama: melalui pendekatan langsung, yaitu upaya-upaya mengarah pada permasalahan dan isu-isu yang sedang dihadapi remaja; kedua: melalui pendekatan tidak langsung, yaitu upaya-upaya yang dilakukan mengarah pada pendekatan skill atau peningkatan kapasitas.

Kedua metode yang dilakukan di atas merupakan upaya-upaya preventif yang dilakukan oleh Balee Inong Ceurih untuk menangani masalah-masalah yang dihadapi remaja. Balee Inong Ceurih bukan sebuah lembaga untuk menangani masalah-masalah sosial dalam bentuk intervensi secara individu dan bukan lembaga khusus yang menangani masalah remaja, namun lembaga tersebut hadir di tengah masyarakat untuk menjawab berbagai masalah-masalah sosial dan menyukses pembangunan.

Balee Inong dan khususnya Balee Inong Ceurih bukanlah sebuah lembaga yang provit, namun lembaga ini lahir berkat keinginan besar walikota Banda Aceh untuk memberdayakan perempuan dan juga masyarakat secara umum, baik anak- 
anak, remaja dan dewasa. Jika kita melihat perkembangan Balee Inong Ceurih hingga saat ini, mereka telah mampu melaksanakan berbagai kegiatan secara mandiri tanpa harus berharap pada pemerintah kota Banda Aceh maupun WDC (Women Development Centre) dan PP\&KB (Pemberdayaan Perempuan dan Keluarga Berencana).

\section{Peran Balee Inong dalam Menanamkan Nilai-Nilai Pendidikan Kepada Orang Tua Perempuan (Ibu) Agar Dapat Membentengi dan Menanggulangi Pengaruh Perilaku Menyimpang.}

Penelitian ini fokus dilakukan di wilayah Balee Inong Ceurih Kecamatan Ulee Kareng dengan alasan ilmiah yang telah peneliti kemukakan pada latar belakang di atas, bahwa Balee Inong Ceurih terletak digampong Ceurih Kecamatan Ulee KarengKota Banda Aceh dengan jumlah gampong yang tergabung ada tiga gampong yaitu gampong Ceurih, gampong Pango Raya dan gampong Pango Deah. Anggota yang tergabung dalam Balee Inong Ceurih berjumlah 37 (tiga puluh tujuh) orang yang berasal dari tiga gampong tersebut. Balee Inong Ceurih ini diketuai oleh ibu Kasmawati, dan seluruh pengurusnya berasal dari tiga gampong tersebut.

Balee Inong Ceurih merupakan salah satu dari 18 (Delapan Belas) Balee Inong lainnya yang aktif, program-program lahir dari gagasan dan kreatif anggota dan masyarakatnya yang didampingi oleh WDC dan PP\&KB. Adapun programprogram yang telah mereka rencanakan dan laksanakan adalah:

\section{Bidang Pendidikan:}

1. Pelatihan Komputer, pelatihan komputer ini di fasilitasi oleh Women Development Centre (WDC) kerjasama dengan Telkom, output yang diharapkan ibu-ibu di Balee Inong mampu mengoperasikan komputer minimal sekali dapat mengoperasikan program microsoft office, pelatihan ini dapat membantu ibu-ibu di Balee Inong dalam menjalankan aktivitas sehari-sehari di Balee Inong Ceurih dan dimasyarakat.

2. Demo masak, kegiatan-kegiatan juga dimaksudkan untuk mengikat tali persaudaraan ibu-ibu di Balee Inong Ceurih dan meningkatkan kreatifitas ibu-ibu dalam menyajikan makanan, bagi ibu-ibu yang memiliki bisnis dibidang makanan, maka dapat memanfaatkan kegiatan-kegiatan demo masak sebagai ajang untuk meningkat kreatifitas.

3. Pelatihan public speaking, Pelatihan ini diharapkan untuk melatih perempuan agar berani tampil di depan umum, mampu menjadi MC dan sebagainya

4. Sosialisasi tentang bahaya LGBT (Lesbian, Gay, Biseksual dan Trans Gender) yang difasilitasi oleh pemerintah kota Banda Aceh.

5. Sosialisasi tentang Kekerasan dalam Rumah Tangga (KDRT), KDRT yang dimaksudkan tidak hanya kekerasan suami terhadap istri, tetapi juga kekerasan orang tua terhadap anak yang dilaksanakan oleh P2TP2A

6. Sosialisasi tentang trafficking

7. Sosialisasi gender 


\section{Bidang Kesehatan}

1. Seminar dan penyuluhan, kegiatan yang telah dilaksanakan adalah penyuluhan gizi dan sosialisasi kanker servik.

2. Sosialisasi tentang bahaya narkoba yang dilaksanakan di kantor kecamatan.

\section{Bidang Ekonomi}

1. Pelatihan packing product dan manajemen pemasaran, Pemerintah Kota Banda Aceh berharap setiap satu gampong memiliki satu produk yang dihasilkan untuk dapat dipasarkan.

2. Pelatihan keterampilan/merangkai bunga, dimaksudkan untuk melatih ibu-ibu menjadi perempuan yang kreatif dan mampu menghasilkan karya yang dapat dipasarkan agar menambah pendapatan untuk membantu ekonomi keluarga.

3. Pengelolaan dana bergulir yang difasilitasi oleh Women Development Centre di dukung oleh Ford Foundation, dana bergulir saat ini berjumlah Rp. 21.000.000,- yang dapat dipergunakan oleh anggota Balee Inong sebagai modal usaha.

\section{Bidang Sosial:}

Arisan Balee Inong Ceurih, kegiatan arisan dimaksudkan untuk mengikat tali persaudaraan ibu-ibu di Balee Inong Ceurih, pertemuan arisan ini dilaksanakan dilaksanakan satu bulan sekali, sekaligus di isi dengan berbagai kegiatan-kegiatan yang telah diprogramkan.

\section{Bidang Keagamaan:}

1. Perayaan hari-hari besar keagamaan, yaitu: maulid, peringatan isra' dan mi'raj.

2. Mengunjungi anggota Balee Inong yang mengalami musibah, baik musibah meninggal dunia dan sakit.

3. Kegiatan-kegiatan keagamaan: Pelatihan Tajhiz Mayit bekerjasama dengan Dinas Syariat Islam Kota Banda Aceh.

Apa yang peneliti sampaikan di atas adalah beberapa program kerja yang telah dijalankan oleh Balee Inong Ceurih yang difasilitasi oleh Pemerintah Kota Banda Aceh melalui WDC dan PP\&KB Kota Banda Aceh dan didukung oleh lembaga Ford Foundation. Program kerja yang dirancang oleh Balee Inong Ceurih di atas dapat mewakili dari berbagai aspek, yaitu sosial, ekonomi, pendidikan, kesehatan, budaya dan agama. Program kerja Balee Inong Ceurih yang peneliti sebutkan di atas tentu saja berbeda setiap tahunnya, program kerja menyesuaikan dengan isu-isu dan kebutuhan Balee Inong dan masyarakatnya.

Balee Inong Ceurih sampai hari ini aktif dalam pelaksanaan berbagai kegiatan di gampong, kegiatan mereka tidak hanya terbatas pada kegiatan-kegiatan pengembangan kapasitas perempuan saja, namun kegiatan-kegiatan mereka 
mengarah pada segala aspek pembangunan, baik ekonomi, sosial, pendidikan, kesehatan, budaya dan agama. Hal ini sesuai dengan harapan WDC dan PP\&KB, karena pada prinsipnya masalah-masalah yang terjadi dalam kehidupan bermasyarakat tidak hanya pada satu aspek saja, tetapi multi aspek dan pola penyelesaian masalahnya juga multi aspek.

Beberapa program yang telah dijalankan oleh Balee Inong Ceurih, pada prinsipnya adalah bagaimana berupaya untuk memberdayakan perempuan, mendidik dan meningkatkan kapasitas perempuan di Balee Inong Ceurih untuk memahami dan peka terhadap isu-isu sosial yang terjadi dalam kehidupan masyarakat. Program-program yang dirancang juga diharapkan perempuan di Balee Inong Ceurih berfungsi dan berperan sebagai kontrol sosial masyarakat.

Program Sosialisasi Bahaya LGBT misalnya, selain memberikan informasi penting kepada remaja, juga dapat memberikan informasi penting bagi Ibu-ibu di Balee Inong Ceurih agar mampu berperan sebagai kontrol sosial di masyarakat. Berikut ini peneliti mengutip tanggapan Illiza Sa'aduddin Djamal sebagai Walikota Banda Aceh di media serambi online, pada saat pelaksanaan kegiatan Sosialisasi Bahaya LGBT oleh Balee Inong Ceurih pada tanggal 24 Maret 2016 di Meunasah Gampong Ceurih. Pada saat itu, materinya juga disampaikan oleh Ibu Illiza sendiri. Illiza mengatakan:

"Penggunaan gadget tanpa kontrol oleh anak usia dini juga sangat berbahaya dalam perkembangan anak. Mirisnya lagi, saat ini banyak ditemukan orangtua yang menfasilitasi anaknya dengan gadget. Perlu kontrol dari orangtua terhadap anak, mulai dari tontonan TV, film, lagu, hingga pergaulan mereka sehari-hari. Amati perilaku anak-anak kita, jika ada gelagat yang tidak biasa orang tua harus cepat tanggap." (http://aceh.tribunnews.com diakses tanggal 1 Agustus 2016).

Jika kita mengamati program-program Balee Inong Ceurih, programnya juga mengarah pada bagaimana perempuan Balee Inong Ceurih harus mampu berperan menjadi kontrol sosial di masyarakat. Salah satunya adalah sosialisasi bahaya LGBT. Dengan adanya sosialisasi bahaya narkoba, harapannya adalah perempuan Balee Inong Ceurih dapat berperan dan berupaya membentengi, menanggulangi perilaku menyimpang.

Peran Balee Inong Ceurih dalam menanamkan nilai-nilai pendidikan pada perempuan Balee Inong Ceurih dilakukan melalui pola pendidikan atau peningkatan kapasitas. Peningkatan kapasitas dapat berupa pelatihan, seminar, penyuluhan dan diskusi-diskusi di Balee Inong Ceurih seperti yang telah peneliti sampaikan diatas. Pendidikan tersebut diharapkan untuk mendidik dan menambah ilmu pengetahuan bagi perempuan di Balee Inong Ceurih, sehingga ketika perempuan memiliki ilmu dan pengetahuan yang baik, maka ilmu dan pengetahuan tersebut dapat ditransfer kepada anak-anaknya, harapannya agar anak-anaknya memiliki sikap yang baik dan tidak terpengaruh pada perilaku menyimpang. Di sisi lain, perempuan adalah orang yang memiliki perasaan peka terhadap keluarga. Perempuan adalah orang yang paling banyak bersosialisasi dengan anak-anaknya di rumah, sehingga peran perempuan dinilai sangat penting untuk mendidik anak-anaknya.

Program-program peningkatan kapasitas lainnya, secara tidak langsung sebenarnya juga mengarahkan bagaimana perempuan memiliki peran dalam 
membentengi dan menanggulangi pengaruh perilaku menyimpang, misalnya program pemberdayaan ekonomi yang di dukung dengan dana bergulir. Logikanya adalah jika perempuan di Balee Inong memiliki usaha di bidang ekonomi, maka paling tidak perempuan dapat membantu ekonomi keluarga, ataupun dapat membantu pendidikan anak-anaknya sehingga kemudian anak-anak mereka memiliki pendidikan yang baik dengan harapan tidak terjerumus pada perilaku yang menyimpang, sekalipun pada dasarnya tanggung jawab mencari nafkah itu ada pada suami, namun perempuan mungkin saja dapat membantu kebutuhan keluarga demi tercapainya keluarga yang harmonis.

Berikut penuturan ketua Balee Inong Ceurih Ibu Kasmawati: "Pemberdayaan ekonomi dinilai bagian yang sangat penting juga, selain program-program kerja yang lain, jika ekonomi masyarakat dalam kondisi yang baik dan mencukupi, maka Insya Allah persoalan yang lain juga akan ikut baik, misalnya pendidikan, kesehatan, sosial dan sebagainya. Masalah broken home yang terjadi hari ini, kebanyakan disebabkan oleh persoalan ekonomi yang tidak mencukupi, sehingga membuat keharmonisan tidak terjaga lagi". (Hasil wawancara tanggal 3 Juni 2016)

Peran yang dilakukan oleh Balee Inong Ceurih dalam menanamkan nilai-nilai pendidikan kepada orang tua perempuan (ibu) agar dapat membentengi dan menanggulangi pengaruh perilaku menyimpang dilakukan dengan pola pendidikan atau peningkatan kapasitas. Pertama: peningkatan kapasitas dapat dilakukan secara langsung terkait dengan isu-isu sosial yang sedang terjadi dengan harapan perempuan Balee Inong Ceurih dapat menanggulangi perilaku menyimpang. Kedua: sebagian program-program peningkatan kapasitas lainnya yang dilakukan oleh Balee Inong Ceurih, sebenarnya secara tidak langsung juga mengarahkan perempuan dapat membentengi dan menanggulangi perilaku menyimpang, misalnya program pemberdayaan ekonomi yang telah peneliti bahas di atas.

Peran Balee Inong sebagai salah satu institusi lokal dinilai sangat penting dalam menangani masalah-masalah sosial di gampong, karena gamponglah yang paling paham dengan kondisi kehidupan masyarakatnya. Penanganan masalahmasalah sosial tentu tidak terlepas dari konsep pemberdayaan dan nilai-nilai Islam. Program-program yang dirancang berdasarkan dari gagasan-gagasan Balee Inong dan dilaksanakan untuk mereka dan masyarakat secara umum. Apa yang telah dilakukan oleh Balee Inong Ceurih hari ini telah menunjukkan peran yang baik dalam penanganan masalah-masalah sosial termasuk menanamkan nilai-nilai pendidikan Islam kepada remaja dan perempuan (ibu) di Balee Inong Ceurih. Penanganannya dilakukan melalui segala aspek, baik sosial, pendidikan, ekonomi, kesehatan, budaya dan agama. Penanganan yang dilakukan, baik itu dilakukan secara langsung maupun tidak langsung seperti yang telah peneliti jelaskan di atas.

\section{KESIMPULAN}

Masalah-masalah sosial remaja yang terjadi hari ini merupakan fakta sosial yang harus dilakukan upaya-upaya pemecahannya, Balee Inong Ceurih telah menunjukkan perannya, sekalipun perannya berada pada upaya-upaya preventif. 
Karena Balee Inong bukanlah lembaga untuk menangani masalah-masalah sosial dalam bentuk intervensi secara individu dan bukan lembaga khusus yang menangani masalah remaja, namun lembaga tersebut hadir ditengah masyarakat untuk menjawab berbagai masalah-masalah sosial dan menyukseskan pembangunan. Upaya dan peran yang dilakukan oleh Balee Inong Ceurih dalam menangani masalah kenakalan remaja tidak hanya diarahkan kepada remaja saja, namun juga dilakukan kepada orang tua mereka khususnya orang tua perempuan. Pendekatan yang dilakukan adalah melalui dua pendekatan, yaitu: pertama, melalui pendekatan langsung, yaitu upaya-upaya mengarah pada isu-isu atau masalah-masalah yang sedang dihadapi remaja; kedua: melalui pendekatan tidak langsung, yaitu upaya-upaya yang dilakukan mengarah pada pendekatan skill atau peningkatan kapasitas.

\section{REFERENSI}

Elly M.Setiadi dan Usman Kolip. 2011. Pengantar Sosiologi, Pemahaman Fakta dan Gejala Permasalahan Sosial: Teori, Aplikasi dan Pemecahannya. Jakarta: Kencana Prenadamedia Group.

Hadi, Sutrisno. 2000. Metodologi Penelitian. Yogyakarta: Andi Offset

http://aceh.tribunnews.com

http://hukum.unmuhjember.ac.id

Masrizal. 2015. Pengendalian Masalah Sosial Melalui Kearifan Lokal. Banda Aceh: Syiah Kuala University Press.

Nugroho, Heru. 2001. Negara, Pasar dan Keadilan Sosial . Yogyakarta: Pustaka Pelajar.

Sabirin. 2015. Pemberdayaan Masyarakat Berbasis Kearifan Lokal. Yogyakarta: Samudera Biru.

Soetomo, 2008, Masalah Sosial dan Upaya Pemecahannya. Yogyakarta: Pustaka Pelajar.

Soetomo. 2008. Strategi-Strategi Pembangunan Masyarakat. Yogyakarta: Pustaka Pelajar.

Sugiyono. 2010. Metode Penelitian Kuantitatif, Kualitatif dan RED. Bandung: Alfabeta.

Soekanto, Soerjono. 2010. Sosiologi; Suatu Pengantar. Jakarta: PT. Raja Grafindo Persada. 